\title{
AUDIENCE PARTICIPATION IN CONTEMPORARY LITHUANIAN THEATRE: A CONFLICTED ADAPTATION OF THE WESTERN TRADITION
}

Summary. This article explores how audience participation practices were introduced into Lithuanian theatre in the last three decades (between the early '90s and the late 2010s) and how the audience participation methods of the 1960s Western theatre are/were being implemented into contemporary Lithuanian theatre projects. The key goal of this article is to examine the evolution of audience participation and collective theatre tradition in Lithuanian theatre by analysing the preconditions for participatory practices in the country's theatre scene and defining the scope and contradictions of participation in the latest examples of contemporary Lithuanian theatre practices. These contradictions are also apparent in contemporary Western performative practices, which have already distanced themselves from the collective theatre movement of the ' 60 s and the ' 70 s and the political agenda of the performances of that time, selectively retaining only limited participatory aspects of the environmental theatre culture as a new form of entertainment. Similar limited levels of participation in Lithuanian theatre can be based on a different premise - that changes in spectators' habitude cannot catch up with the newly (re)introduced theatrical ideas after the 1990s, and that theatre creators are still trying to cautiously synchronise conventional observation tactics and modern theatre hierarchies with the interactive ones, thus slowing down changes in staging and spectatorship strategies as well.

The article focuses on academic texts by Lithuanian theatre researchers Ramunè Balevičiūté, Rasa Vasinauskaitė, Rūta Mažeikienè, Jurgita Staniškytė, Vaidas Jauniškis, Lina Michelkevičè, and others to illustrate the discourse of audience participation analysis and to present different stages of the participatory tradition in the historiography of Lithuanian theatre. For international context, history, and mechanics of audience participation, texts by Erika Fischer-Lichte, Michael Kirby, Richard Schechner, Gareth White, Gay McAuley, Johan Huizinga, and others are used.

Keywords: art, theatre, Lithuanian theatre, audience participation, collective theatre.

\section{INTRODUCTION}

Even though in the last decade Lithuanian theatre saw many more performative approaches in stage productions than before and a new way of thinking about theatrical forms and the relationship between actors and spectators, in a lot of ways this search for a new paradigm could be described as conditional, reserved, and still reliant on the conventional past structures of (in linear hierarchy) play-directoractor-representation-spectator, with alternative approaches to the theatrical process being limited and noticeable. As participatory culture is becoming a global phenomenon in the 21 st century consumer societies, more and more Lithuanian theatre makers are also starting to experiment with new forms of audience participation, trying to implement some aspects of the 1960s Western performative theatre, which the audiences of Lithuanian theatre largely discovered only after the fall of the USSR. A few of these collectives can be named: the NO Theatre group, associated with director Vidas Bareikis; the "broad profile" theatre syndicate Bad Rabbits, led by stage director Agnius Jankevičius (as well as some individual projects of Jankevičius); Pojūčių teatras (The Theatre of Senses) and Karolina Žernyte; as well as Kaunas-based director Gildas Aleksa and his theatre company Teatronas, which recently started to experiment with environmental practices. Although these (and other) collectives do not necessarily 
achieve the full participation of their spectators, they are all characterised by experimentation with environmental mechanics and looking for a stronger and more "immersive" impact of theatre. However, absence of suitable methodologies (of the scope of those used by Richard Schechner or Allan Kaprow in the '60s) and extensive use of familiar acting and directing manners borrowed from the conventional psychological and modern theatre are not necessarily compatible with the participatory theatrical models. Mere spatial communication (e.g., disruption of spatial hierarchies and letting spectators walk onto the stage) does not work as the only condition for establishing new social relationships during a performance without rethinking the very process of the (co)creation of the performance. These new spatial and social interactions, however, can be traced (sometimes with great success) to paratheatrical performances and gatherings of performance art (e.g., the CREATURE Live ART festival and Alytus Biennial), where audience participation is not an uncommon practice and is implemented without a disruption of the existing theatrical canons. These festivals also tend to structure a community around the performance, thus integrating spectators into the actual world of the performance itself. This example exposes specific problems that the participatory culture faces in the theatre field.

In this article, I explore the evolution of audience participation and the collective theatre tradition in Lithuanian theatre in the last three decadesbetween the early '90s and the late 2010s-by analysing the preconditions for participatory practices in Lithuanian theatre and defining the scope and contradictions of participation in the latest examples of contemporary Lithuanian theatre practices.

\section{THE REFRACTURED PARADIGM}

Active audience involvement in a theatrical act should not be seen as a contemporary phenomenon and must be placed in the context of theatre history. Various levels of participation can be observed in the pre-modern theatre up to the end of the 19th century. More recently, a new actor-audience relationship was formulated in the interwar period by
Antonin Artaud in his theoretical manifesto for the Theatre of Cruelty (1937), the legacy of which inspired many theatre creators in the latter half of the 20th century. Nevertheless, it was only in the late 1950s and well throughout the 1960s that Western culture saw a tangible theatrical revolution and an attempt to restructure the old modern paradigms, which opened new opportunities for theatre, both alternative in their approach to social participation and traditional in the sense of the pre-modern theatrical practices. This was the case of the participatory theatre productions of the late 20th century which could, according to Steve Nelson, be seen as largely extended from the theatrical tradition of the ' 60 s. ${ }^{1}$ On the other hand, even though the theatrical movement of the ' 60 s helped implement the postmodern promise while at the same time denying the great narratives of modernity, the movement did not become a new basis for the mainstream theatre of the time. In these few years during the '60s, significantly expanded boundaries of collective theatre soon lost deeper interest, along with the end of the zeitgeist of the decade. Still, tools and methods of the ' 60 s continued to be implemented on the "alternative" theatre stage and came to serve as conceptual bases for many contemporary theatre productions.

Participation practices of the '60s were strongly influenced by the new phenomena of breaking up time, space, and boundaries between art and life, thus creating new forms of "being together", which were manifested in the Happenings of Allan Kaprow, followed by his theoretical postulates, such as audio lecture How to make happenings. ${ }^{2}$ Michael Kirby considers the new participatory models of Happenings an essential factor that influenced the development of performance. According to him, Happenings, which spread on the international scale in the '60s, influenced not only performance but narrative as well. These new "events" were marked by collective creativity, disappearance of dramaturgical significance, unconventional "specific" places, and public participation practices with greater focus on movement and visual communication. ${ }^{3}$ Another important step can be found in Richard Schechner's formulation of Six Axioms for Environmental Theatre in 1967, which also helped define the new 
participatory role of the audience in the theatrical act, especially with the idea of "the theatrical event [being] a set of related transactions", largely incorporating an exchange between the spectators and the actors. ${ }^{4}$ Erika Fischer-Lichte, analysing the decade, helped popularise the term performative fracture, which describes the dislocation of the theatrical culture of the ' 60 s that opened a new social depth in performance, thus provoking a new bodily presence between the actors and the spectators, and enabled more intense reciprocal circulation of reactions (transactions), governed by the autoreferential autopoietic feedback loop: a mechanical device of the performance that determines how inner and outer reactions of a spectator influence the dynamics of the actors' work. ${ }^{5}$ She explains that only with the emergence of performance art during the '60s performative movement, a new approach to fortuity as a condition of performance appeared and the autopoietic feedback loop gradually returned to the cultural field [after being suppressed during the era of theatrical naturalism and realism], and its manifestations became recognised and desirable. ${ }^{6}$

Fischer-Lichte points out that the building strategies that construct a sequence of attempts or representations of acting always refer to three closely related actions: the actor-audience exchange of roles; the creation of a spectator-actor community; and various ways of mutual contact: distance-privacy, gazebodily contact. ${ }^{7}$ These strategies, according to her, are not only about depicting their implementation but are actually implemented through the exchange of roles, community building, and so on. After the '60s, action is no longer just declarative, because a viewer gets a chance to fully experience the new changes. ${ }^{8}$ It is worth pointing out that the performative fracture of the ' 60 s helped establish the idea of a joint presence of the actor and the spectator as well as opened new ways of participation for the audience in general. Ronald J. Pelias and James Van Oosting notice that, even though they are no longer considered avant-garde, the creative experiments of the '60s helped institutionalise new relationships between the artist, the audience, and the text. According to them, sometimes aesthetic conventions determine the nature of these relationships. In other cases, political or psychosocial goals dictate their interactions. ${ }^{9}$ This need for a more engaged audience, which may transgress into a political entity, is somewhat apparent today as well, as seen in Gay McAuley's study Space in Performance in which the author illustrates how the spectator shifts from being a dissociated viewer to being an active participant in the creative process that allows energy exchanges to occur, thus guiding performers and spectators into a new social reality. ${ }^{10}$

More recent, radical, and transgressive position can be found in Jacques Rancière's The Emancipated Spectator, where he reinforces the ideas of the ' $60 \mathrm{~s}$ theatrical movements and notes that theatre needs a new tactic of spectator organisation that requires the realisation of theatre's promise-a drama that implies a new expression of action, engaging spectators to the maximum and forcing them to reach the goal of co-performance with the actors. ${ }^{11}$ Refering to Bertolt Brecht and Artaud, Rancière reveals a suggestion to remove the viewer from a calm, astonishing position altogether, destroying his theatrical illusion and placing the viewer at the center of the theatrical action, transforming a passive audience into an active body of the theatre community. ${ }^{12}$ Rancière considers theatre an exemplary community form, which is fundamentally contrary to the distance created by representation, and defines theatre as the only place where the audience is confronted with itself as a collective. ${ }^{13}$

\section{SLOWING-DOWN FACTORS IN THE LOCAL CONTEXT}

The long-awaited political transformation of the country in the 1990s helped introduce and somewhat implement the new participatory models in Lithuanian theatre. On the one hand, it can be attributed to fundamental structural changes in Lithuanian society after the secession from the Soviet Union and the rapid expansion of freely available information. On the other hand, the elimination of the former political pressure from the USSR and the abolition of institutional censorship were also important. Cultural isolation during the years of the Soviet occupation can be understood as one of the main factors that prevented the exploration 
of the new theatrical forms of the '60s from happening at the same time and on the same scale as in Western Europe and the US. In Lithuanian theatre, these practices were (re)discovered only in the late '80s and the '90s, with noticeable caution and slow transition from the conventional theatre mechanics to the new ones, with the latter never receiving the same attention. Only some aspects of the accustomed theatrical norms were reconsidered right away and were open for interpretation, such as space reconfiguration and rethinking: something that the directors of the time had at their disposal and could freely implement to respond to the new sociopolitical reality. This subjection to political conditions can be found in Ramunè Marcinkevičiūtès analysis of the phenomenon of unconventional spaces in Lithuanian theatre, where she presents a model of change in the actor-viewer relationship, depending on the new social presence mechanics caused by unconventional space. Marcinkevičiūtè compares environmental theatre practices to ideological conditions that require a new way of modeling space and its subjects-not only spatial but also social. The category of theatrical space in the new context of theatre, according to Marcinkevičiūte, "functions not only as an ideological concept of artistic manifestoes but also as an instrument of communicating with the audience programmatically."14

Participation practices of Lithuanian audiences tend to be reserved and formalistic, and their development in the mainstream theatre can be described as being set back by the inertia of the theatrical tradition of the time. For example, Ramunè Balevičiūte traces some aspects of participation and interactivity in the production of Čia nebus mirties (There Will Be No Death Here, 1988), directed by Rimas Tuminas, as well as a few other stage productions of his from the same period. Balevičiūte observes that Tuminas implemented an innovative principle of staging, which is characterised by the abandonment of sticking to the text, the priority of an actor's individuality, spectator interaction opportunities, and the process being valued more than the result. ${ }^{15}$ Even though some of these principles in theory were on a direction to participation, in practice they were based on conventional dramatic mechanisms of representational theatre and limited to breaking "the fourth wall" and implementation of improvised and politically-engaged text. ${ }^{16} \mathrm{It}$ can be pointed out that similar principles were not uncommon in the works of the already established generation of directors in the late-20th-century Lithuanian theatre but were never shown in their full potential. This slow progress can also be attributed to a lack of engagement and interest in participation practices and collective theatrical forms by the new generation of theatre creators in the '90s, of whom Oskaras Koršunovas was the most famous and productive. In her article about the early creative practices of Koršunovas in the early '90s, Rasa Vasinauskaitè notes that Koršunovas' creative style, even though it wiped away the established previous direction of Lithuanian theatre, "turned not to the traditions of the ' 60 s and the '70s world theatre, the allusions to which could be seen in the aesthetics of Jonas Vaitkus or Eimuntas Nekrošius, but to the early-20th-century searches of the modernists that were once adopted by our first stage professionals." ${ }^{17}$ This revisionism is clarified by Jurgita Staniškyte, who observes that the modern and the postmodern expressions had not encountered one another in a conflicting way in Lithuanian theatre, and that is why no radical actions or "antimodern gestures" were implemented. Koršunovas, Sigitas Parulskis, and even Bernas Šarka, according to Staniškytè, combine different modern theatre traditions and "use the universal vocabulary of art, incorporating its fragments into the structure of the new performance, thus creating an illusion of continuity." ${ }^{18}$

Vaidas Jauniškis finds the first Lithuanian experiments based on the tradition of Happenings and performance art in the ' 80 s and mostly within communities of artists and composers, not the theatre community. These were festivals in Anykščiai and Druskininkai as well as early creative practices of Nomeda and Gediminas Urbonas, artist collectives Žalias lapas, Post Ars, and others. ${ }^{19}$ Participatory, collaborative, immersive, and other theatrical practices in the present day Lithuanian theatre, according to Jauniškis, are toned down only by the fact that the country is still isolated from global avantgarde tendencies, and new practices infiltrate our 
theatrical field through occasional festivals and media. These tendencies of isolation also manifest themselves in the cultural discourse and present a lot of terminological confusion. Jauniškis illustrates this by the example of immersive performances of Eric Jorris and his company Crew and their productions C.a.p.e Brussels, C.a.p.e. Horror, and C.a.p.e. Anima, performed in the New Baltic Dance festival in 2015: none of them were presented as "immersive performances", thus staying within the more familiar categories, like "choreography". 20

\section{THE SCOPE OF PARTICIPATION}

Many more examples of participation practices in Lithuanian theatre can be traced back not only through specific interactivity but also through space building strategies, as indicated before. Marcinkevičiūte notes that, in the practice of Lithuanian theatre, there are relatively few examples of pure environmentalism. She describes the example of Saulius Varnas' environmental theatre at Panevėžys Drama Theatre in 1990 as one of the first attempts to apply this model. The given example can be seen as a true environmental performance with utilisation of different spaces not only for aesthetic purposes but also thematically and conceptually. Another example given by Marcinkevičiūtè is the production of Smèlio klavyrai (Claviers of Sand, 1990) by Jonas Jurašas at the Kaunas State Academic Drama Theatre (today the National Kaunas Drama Theatre) and its usage of non-traditional spaces, which spurred the environmental theatre and non-traditional art festival held at the same institution in $1999 .^{21}$

Just like in the Western environmental practices of the '60s and the '70s, bolder and more inclusive creative experiments were tested not on the big stages but by marginal theatre companies. One of them, Edmundas' Studio 3, founded in 1991 by director Audronė Bagatyrytè and actor Edmunas Leonavičius, approached the theatre medium through a reflection of Jerzy Grotowski's theatrical ideas, as noted by Rūta Mažeikiene. ${ }^{22}$ She describes their performances as excluding the usual stage space and other attributes of the conventional performance as well as challenging the traditional spectator-observer structural frame and emphasising sensual communication of the participants. To get audiences directly involved in the theatrical action, the creators of Edmundas' Studio 3 were looking for new, interactive ways to connect the actors and the spectators, e.g., by locating their performances in small spaces with very small audiences. ${ }^{23}$

This attention to small audiences is also seen in recent productions of the alternative Lithuanian theatre and could be defined as an aspect of local participatory theatre in general. Jauniškis explores participatory performances of the new generation of alternative theatre creators. In the performance piece Dvi su puse minutes (Two and a Half Minutes, 2016) by actordirector Paulius Markevičius and the House of Puglu company, the viewers are guided through a labyrinth while surrounded by saxophone sounds played by the young free-jazz collective Katarsis 4. Jauniškis describes the experience: “Then, after a few minutes, all spectators sit with the performers in two rows opposing each other, touching each other's knees and talking about times when they were afraid. This way, the first part, which caused inconvenience, is turned into a kind of confession and memories of similar states. After some performers' confessions, the audience starts to speak. It is a kind of direct-experience theatre, in which there are different reactions, but the essence is participation and being together." ${ }^{24} \mathrm{~A}$ similar kind of intimacy can be found in a few other examples of the alternative Lithuanian theatre. Many participatory and immersive elements can be observed in the production of Š.T.C., arba Šiuolaikinis tolerancijos centras (M.T.C., or The Modern Tolerance Center, 2014) by the theatre syndicate Bad Rabbits, where participation was implemented by splitting spectators into smaller groups and fostering interactions with the improvising actors, thus aspiring to create a new sense of intimacy and co-presence. The production of Otelas (Otello, 2018) by the Teatronas company also looks to implement the new intimacy by holding the performances in small Soviet-era apartments of real people as well as limiting the number of spectators to around ten per performance. However, the performance does not incorporate any participatory elements and shields itself from the spectators with "the fourth wall", letting the audience "observe 
the actors of the Shakespeare's tragedy in their own environment as if through a glass of an aquarium.". ${ }^{25}$

In recent years, a similar approach to engaging smaller audiences could also be seen on the mainstream theatre stage. One of the more notable examples is the production of Kodas: HAMLETAS (Code: HAMLET, 2016) by director Olga Lapina at Russian Drama Theatre of Lithuania, based around the concept of the escape room game format, described by Staniškyte as an example of immersive theatre which does not function solely on the individual level and instead attempts to involve the spectators as a group, thus fostering social group dynamics. ${ }^{26}$ The production could be compared to the world famous production of Sleep No More (2011) by Punchdrunk, which popularised some elements of participation that are now being associated with immersive theatre in general: masks, maze-shaped spaces, and "workable" participant group sizes-all integrated into the production of Kodas: HAMLETAS, with an emphasis on the design of walkable spaces. Staniškyte observes that such envisioned environments "create a sense of theatre as a collective trap-a physically challenging social experience in which intellectual, psychological, social, and creative skills of the audience are tested."27 On a much bigger scale, Koršunovas, who concentrated more on the modernist theatrical canon in the '90s, also engaged with site-specific environmental performances. One of the examples could be seen in the production of Egle žalčiu karaliene (Egle the Queen of Serpents, 2016), performed twice in the abandoned former Vilnius Red Cross Hospital during the annual Sirenos theatre festival in 2016, but with less interactivity and sparse participation. This duality of the performance is summed up by Kristina Steiblytè: "If successful, Egle žalčiu karalienè turns into a conversation [...] with a real person. And if it fails, one can settle for the feeling of frustration appearing in the hustle of the audience or dream of seeing the installation and the performance with a small group or, even better, alone."28

The last example illustrates the limitations of environmental as well as participatory theatre, where a performance can be reduced to an excursion or, in some cases, a guided tour and fail to produce a new kind of social engagement with the spectators or a new kind of meaning creation, especially when the spectators are left unattended for too long. The social aspect, however, occurs more noticeably in chamber performances by smaller theatre collectives and performance art events held in various places that have some attachment to local or selfformed communities. These small experimental spaces and a less pronounced industrial approach can be traced back to the '60s and seen as successors to the theatrical communities of the time. This indicates a theatrical model where people participate not only as spectators but partake in cultural processes as community members. Mažeikiene explores these community-based theatre initiatives in Lithuanian theatre by considering one of the earliest examples of the community-engaging theatre: the performance of Pro Memoria Šv. Stepono 7 (1995), organised by director Vega Vaičiūnaitė and the Miraklis environmental theatre company. The production happened thanks to a successful collaboration between the creators and local community members from one of the Vilnius Old Town quarters. A few other examples of the community-integrating theatre named by Mažeikiene were produced by the Kaunas contemporary dance company AURA: Tylus ejimas (A Silent Walk, 1999), performed together with seniors, Kelias (Road, 2001)-with people with mobility disabilities, and re-gi-ne-re-gi (see-not-see, 2002) - with blind people. Mažeikienè also points out more recent projects, one of them is by the Psilikono teatras collective, called Šančiu lape pasikoré (The Šančiai Fox Hanged Itself, 2013), produced in cooperation with a Šančiai (a neighbourhood in Kaunas) based NGO working with ex-prisoners and helping their reintegration into society. ${ }^{29}$

\section{THE PROBLEM WITH CONSOLIDATION}

The above examples illustrate the safe distance that the Lithuanian theatre creators maintain by not diving straight into the unconditional demolition of the fabrics of spectatorship, as opposed to The Performance Group and The Living Theatre of the '60s and the '70s. However, principal questions arise: in general, how well does the participatory model function in theatre and does it really bring any new necessary qualities to the conventional theatrical experience? 
It can be observed that, even though the theatrical movement of the '60s, by its first performances and environmental theatre, greatly expanded the theatrical scope of the time, audience participation would not always produce a positive outcome, and in some cases it would only reveal how much "the laws of performance" are disrupted by a social presence of an emancipated spectator who cannot differentiate between fictional and social realities. Fischer-Lichte refers to Dionysus 69 (1968) by Schechner, during which the overwhelming acceptance of the tactile role of spectators greatly outweighed the tactilewatching dichotomy. She presents how it became evident that, when viewers are allowed to actively and physically engage with the actors, they get involved without any limits and let themselves disassociate from moral and ethical norms, thus possibly damaging the actor that they are touching. According to her, this example shows that when the bodies of the audience are directed towards the actor, some of them see in it only a suggestion of closeness and intimacy, so the viewer is, in a sense, not ready for the destruction of dichotomies that traditionally separate viewers from performers, and this phenomenon often is unexpected. ${ }^{30}$ This example can be used as a perspective on the mechanics of power and power conflicts that are present in the theatrical space.

The above principle in Lithuanian theatre can be illustrated by Staniškytës review of the performance Maištas (The Rebellion, 2016) by Jankevičius, where spectators were not playing along with the planned course of the performance after some participatory elements were introduced (e.g., an invitation to leave the auditorium and walk onto the stage, where a "revolution village" was erected) and the former theatrical structure was interrupted. She notes that a superficial attempt to involve the audience without creating a more sustainable social structure prevents a longterm communication with the viewers from taking place: "Once freed from the theatrical conventions of passive spectatorship, audiences are not willing to go back." ${ }^{31}$ It can be observed that, when a group of spectators does not consolidate into a community during the performance, they may become a crowd instead, and break away to social reality as the performance loses its power and impact to the spectators.
In exceptional cases, it is precisely the consolidation of the audience from where a need for action emerges, sometimes going beyond the goals of the creators themselves. While it was very true in the performances of The Living Theatre like Paradise Now (1968), where the spectators went to the streets to protest hand in hand with the creators, as well as in the actionist performances of Hermann Nitsch or in the case of the political guerilla theatre, on the Lithuanian theatre stage such phenomena (with a few exceptions) are basically non-existent. It is exemplified by Marcinkevičiūte, who refers to Kristian Smeds' play Woyzeck, performed at the State Youth Theater in 2003, and the mediation techniques tested in it (the actors were destroying a parked car in a street just outside the theatre and broadcasting the action live to the spectators inside the building). She interprets this as an example of how theatre is no longer able to take the viewers into the streets and out of their comfortable and safe positions and to become a political act. ${ }^{32}$ This illustrates that environmental theatrical structures alone are not sufficient to provide new social dynamics in theatre. New spatial experiments and reconfiguration strategies, although creating alternative transgressive spaces, do not guarantee a social change. Quoting Marcinkevičiūtè, "[...] an alternative space does not mean a social protest against someone." 33 It can be speculated that the actual consolidation of the actor and the spectator occurs only when the practiced power structures and vertical relationships fall for the sake of community, even if only during the theatrical act. This observation is supplemented by Staniškytè, who adds that

audience members do not engage in acts of democratic participation, resistance or social critique, but rather in entertaining acts of simply having fun while playing, cooking or singing along. Various actions devised in order to turn individual spectators into a protest community fail to create "an impression of a space of freedom" (Gareth White) or a laboratory of deconstruction, where the modes of community building via carnivalesque actions can be disclosed and openly analysed. The staged environment of the protest village 
[as was the case with Maištas] retains an aura of artificial Revolution-land, where spontaneous communities of fun are created. ${ }^{34}$

For an organic participation to happen and to provide a positive outcome, a few criteria have to be met. One of them is the expansion of the spectators' activity level during a performance, which reveals the scale of participation. Pelias and Oosting argue that the range of spectatorship varies between the non-active and pro-active modes, which corresponds to the spectators' ability to become co-producers and producers of the performance (as well as meaning) in the interactive and pro-active activity zones, or just limit themselves to being respondents (in the active) and receivers (in the non-active). ${ }^{35}$ Another criterion is the need for new forms of presence in the collective theatrical space, which corresponds to the social aspect of participation. Maaike Bleeker describes the phenomenon of presence as a temporal and spatial proximity of the performer and the audience during live performance and finds similarity in the concept of co-presence by Hans Thies Lehmann. According to Bleeker, the concept of presence can also be interpreted by the meanings found in the phenomenological discourse, which define the presence as the body (in the phenomenology of Edmund Husserl) and (in the phenomenology of Maurice Merleau-Ponty) through the body. ${ }^{36}$

In her analysis of participation conflicts in Lithuanian art, Lina Michelkevičè provides several modes (transactions) of spectatorship intensity, which could be adapted to theatre as well. She defines the first one as a companion transaction that pursues a common goal by investing in a variety of human capabilities and believing in advantages of collective labour. The horizontal power dynamics of such a deal between the actors and spectators is noticed by Michelkevičè not only in interactions of artists but also in projects related to artistic activism. Another transaction is that of associates who work in situations created by artists (initiators) - they do not pursue common goals but, by acting in a defined context, become, according to Michelkevičè, a fundamental condition for the creation and functioning of the work. The third type of transaction-co-authors-operates in everyday projects that take place in the context of non-committed communication, and the participants do not seek to add any new or collaborative value, unlike in the other types of transactions. ${ }^{37}$ Such relationships can turn into social performance acts, but most often they only allocate social transactions by transforming them into artistic performances. Michelkevičè points out that this provokes different reactions from spectators, which can be directed in two ways: towards an aesthetic performance or a social and political one. ${ }^{38}$

A positive outcome of these transactions could be that, as described by Johan Huizinga (on the condition that participation grows into community), a game community tends to become a permanent one, even after the game has ended. In his opinion, the feeling of being "alone together" creates unrivaled situations of sharing and separation from the outside world. Such states of experience do not lose magic even after a specific game has ended. ${ }^{39}$ Talking about the context of Lithuanian theatre, Mažeikienè, however, endorses the view of Jerzy Grotowski after his failed attempt to fully implement performance as ritual-that the modern-day spectator lacks community experience that would allow him to participate directly in the ceremony, and that his reactions are not authentic but traditionally rational and censored by the norms of everyday life. Mažeikienè notices that these problems led Grotowski to seek out new ways of cognition and to abandon direct involvement of the audience. ${ }^{40}$

Many participatory conflicts stem not only from lack of involvement but also from specific power dynamics apparent during a performance. On a fundamental level, actors and spectators engage each other from different positions and have functions engraved into their statuses. Such power positions, coming from social status as well as artistic competence, can be compared to the concept of cultural capital by sociologist Pierre Bourdieu. ${ }^{41}$ Actors, out of all creators, have the most control of the material of their bodies, and their cultural capital is manifested not in the work of art that they create but in themselves as objects. Such distribution of cultural capital held by actors occurs only during 
the theatrical act-an opportunity for viewers to get a part of that cultural capital symbolically as well as a power position from which actors can manipulate spectators into production of meaning or experience. According to Michel Foucault, even when sometimes initiating turning the theatrical process to a wanted direction, the spectator is still dependent on the informational advantage available to the actor. Thus, the union of the two subjects becomes closer to the one of imitation, because it takes place under the conditions of the opposite subject thus consolidating its dominance over the weak. However, in spite of this uneven ratio, the power position of the actor is not necessarily a negative phenomenon. According to Foucault, power not only suppresses and masks, but also produces reality, which happens in the process of production and consumption of the theatrical process as well. ${ }^{42}$

A similar idea can be found in Staniškytës article "Spectatorship, Politics and the Rules of Participation", in which she observes that contemporary theatre practices serve both as "manipulation machines" and a tool for deconstructing the mechanics of manipulation. She uses the example of Maištas, explaining how this dual function of participatory theatre could not only provide political depth to the performance but also serve in the implementation of ideology. The negative outcome of this approach unfolds when the participation itself gets lost among the various pastiches of modern theatre technicians and turns into didactics. ${ }^{43}$ Staniškytè notices a problem in Lithuanian theatre participation where participants are usually given a restrictive framework in which to make their desired choices as well as being limited by space-building staging strategies. ${ }^{44}$ These barriers contribute to maintaining conventional dialectical dichotomies of the usual paradigms of the audience and can be seen as preventing the rise of the new concepts of participation, such as co-creation and spectatorship as performance. ${ }^{45}$

To evaluate Lithuanian theatre attempts at participatory theatre in the broader contemporary international context, it can be noted that full participation is paradoxically becoming a global rarity in the otherwise highly exploited culture of participation. As the dust settled after the theatrical revolution of the ' 60 s and the '70s, a lot of its elements were integrated into new theatrical productions, but the sincere aspiration of creating a new theatrical world, first envisioned by Artaud, was left out. Nelson claims that the environmental theatre productions of the late 20th century, along with Western societies, have become more defined and controlled, thus avoiding the failure of the first Happenings and at the same time adapting to the oppression of the lost counterculture, but this new environmentalism has so far failed to normalise the unconditional actor-spectator interaction envisioned in the first environmental practices. He points out that the later examples of environmental theatre, unlike their predecessors in the '60s, which deleted clearly defined boundaries between the theatrical act and reality, lack political engagement ${ }^{46}$ and rely on ecstatic techniques typical in postmodern performance. ${ }^{47}$ Similarly, Gareth White notices that environmental theatre and its subsequent evolution into immersive theatre since the '70s have not avoided the reduction of its basic mechanical element-the spatial environment element-and its impact on the behaviour of the viewer. He points out that the popularity of the new immersive performances can be related to the attempt of returning to the level of audience inclusion of the ' 60 s and the '70s, only without the indication of the political context and imperatives of the past. This is the opposite of the creators in the '60s and the '70s, who at the time made strong claims for the political potential that lies in the reordering of audience-performer relationships and the possible freedoms that could be gained by active audiences. ${ }^{48}$ In a predictable way, the participatory practices of the '60s mutated into a simple economic unit and became part of the new participatory culture, eliminating any need for active actions. This position is supported by Staniškyte, who writes that many modern strategies of "liberation" of the spectators were based on the assumption that an active spectator in an aesthetic space can become an active agent in the social field as well, and that any collaboration between the performers and the public can form new social relationships or social realities. She notices that, however, the power of "revolutionary rehearsals" of Augusto Boal or "ecstatic communities" of Richard Schechner has proved to be limited and ineffective, and the "adopted 
and adapted avant-garde strategies of commercial theatres have turned into charming games with the viewer and lost their political potential."49 Balevičiūtè notices a conflict between the storytelling theatre acting in the dimension of poetic reality and the "sensual experience" theatre practices which, according to her, are "limited and it is hard for them to compete with a variety of reality simulations offered by the entertainment industry." ${ }^{50}$ Some of these outcomes can be seen in Lithuanian theatre as well, exposing the limits and fears of the creators to fully submerge into socially charged interactions with the spectators and transfer the theatrical power from the one based on meaning to the one based on action.

\section{CONCLUSION}

In the last decade, Lithuanian theatre has seen many more staging practices, performative concepts, and searches for new ways of audience interactivity and participation than before, which can be traced back to the Western theatrical practices developed over two decades of the second half of the 20th century as well as linked to the recent global participation tendencies in the entertainment industry. Because of the relative cultural isolation in the decades following World War II, Lithuanian theatre creators of the period had perfected conventional theatrical forms (both in production and spectatorship), making these new theatrical mechanics harder to fully implement into the existing fabric of the theatrical tradition as well as for them to challenge the accustomed behaviour of the audience. This can be exemplified by the indifference to participatory models of the younger generation of directors in the early '90s, thus leaving these theatrical forms in the hands of marginal theatre makers. The long isolation during the Soviet times was also apparent in the lack of terminology and confusion of both the audience and in the critical discourse when categorising the newly (re)discovered theatrical practices in the 1990s and the '00s.

Participation practices have become much more pronounced in the last decade of Lithuanian theatre, expanding with the alternative theatre companies like NO Theatre and slowly entering the mainstream theatre culture with the help of theatre festivals like Sirenos. Many of the methods that were produced in the first Happenings and environmental performances of the '60s are also being implemented in Lithuanian theatre today with various degrees of success and not always differentiating between formalist tools for the new ways of audience entertainment and the need for a new social quality of theatre.

This inconsistency could be explained by the selective implementation of participation elements by the creators themselves, trying to balance the loyalty to dramatic fundamentals and the craving for new ways to embrace the spectator. This can result in possible conflicts stemming from the inertia of the conventional theatre structure as well as lack of knowledge of how immersive theatre operates, both on the side of the audience and the actors. Quite often, new physical approaches by Lithuanian theatre creators overshadow the possibility of an open social inclusion, which is also noted by Staniškytė. The same formalistic approaches to and conventional power dynamics during the theatrical act prevent an emergence of the truly social performance in Lithuanian theatre, in which the audience would get a chance to become co-authors and shift from a purely aesthetic community to a political one.

\section{References}

Balevičiūtè, Ramunè. "Apie nenugalimą žaidimo trauką ir potyrių spektaklius." Kultūros barai 5 (2017): 53-55.

Balevičiūte, Ramunè. "Epinio, postdraminio ir žaidybinio teatro sankirtos Rimo Tumino režisūroje." Menotyra 19: 2 (2012): 114-121.

Bleeker, Maaike. "Corporeal Literacy: New Modes of Embodied Interaction in Digital Culture." In Mapping Intermediality in Performance, edited by Sarah BayCheng, Chiel Kattenbelt, Andy Lavender, and Robin Nelson. Amsterdam: Amsterdam University Press, 2010. 38-43.

Bourdieu, Pierre. “The forms of capital." In Handbook of Theory and Research for the Sociology of Education, edited by John G. Richardson. New York: Greenwood, 1986. 241-258.

Fischer-Lichte, Erika. Performatyvumo estetika. Vilnius: Menų spaustuve, 2013.

Foucault, Michel. The Foucault Effect. Studies in Govermentality. Chicago: The University of Chicago Press, 1991. 
Huizinga, Johan. "Nature and Significance of Play as a Cultural Phenomenon." In Performance, Critical Concepts in Literary and Cultural Studies Volume I, edited by Philip Auslander. London and New York: Routledge, 2003. 36-56.

Jauniškis, Vaidas. "Naujos strategijos jaunųjų scenoje." Menotyra 24: 2 (2017): 131-141.

Jauniškis, Vaidas. "Naujosios teatro realybès. Keletas pastabų dèl terminijos." Menotyra 23: 2 (2016): 121130.

Kirby, Michael. "On acting and non-acting." In Performance, Critical Concepts in Literary and Cultural Studies Volume I, edited by Philip Auslander. London and New York: Routledge, 2003. 309-323.

Marcinkevičiūtè, Ramunè. "Netradicinèse erdvėse. Šiuolaikinio teatro nerimas ir naujų vietu trauka." Darbai ir dienos 39 (2004): 7-19.

Mažeikienė, Rūta. "Kolektyviniai naratyvai: bendruomenę ittraukiančio teatro kūrybinès praktikos." Meno istorija ir kritika 11 (2015): 34-45.

Mažeikienè, Rūta. "Postdraminio teatro vaidybos principai ir jų sklaida šiuolaikiniame Lietuvos teatre." Teatrologiniai eskizai 2 (2002): 149-184.

McAuley, Gay. Space in Performance. Chicago: University of Michigan Press, 1999.

Michelkevičè, Lina. "Dalyvavimo konfliktai: Dariaus Mikšio projektas 'Už baltos užuolaidos.' Acta Academiae Artium Vilnensis 74 (2014): 143-155.

Nelson, Steve. "Redecorating the Fourth Wall: Environmental Theatre Today." TDR 33: 3 (1989): 72-94.

Pelias, Ronald J., and James Van Oosting. "A paradigm for performance studies." In Performance, Critical Concepts in Literary and Cultural Studies Volume I, edited by Philip Auslander. London and New York: Routledge, 2003. 215-231.

Rancière, Jacques. The Emancipated Spectator. London, New York: Verso, 2009.

Schechner, Richard. "Six axioms" in Environmental Theatre. New York: Applause, 1994.

Staniškyte, Jurgita. "Daugybingumo formos šiuolaikiniame Lietuvos teatre: postmoderni reprezentacija ar modernios tradicijos tęsinys?" Menotyra 18: 2 (2011): 122-130.

Staniškytè, Jurgita. "Komunikacija kaip auditorijų plètros priemonè: Lietuvos teatru praktikos." In Komunikuoti kultūrą: institucijos, strategijos, auditorijos. Kaunas:VDU, 2015. 165-198.

Staniškytè, Jurgita. "Spectatorship, Politics and the Rules of Participation: Re-discovering the Audience in Contemporary Lithuanian Theatre." Nordic Theatre Studies 30: 2 (2018): 99-114.

Steiblytė, Kristina. "Pragmatiškas infantilumas." Menu faktūra, October 1, 2016. http://www.menufaktura. $\mathrm{lt} / ? \mathrm{~m}=1025 \& \mathrm{~s}=61226$.

“'Teatrono’ premjera: didelè tragedija mažame bute." Menu faktūra, March 6, 2018. http://www.menufaktura. $\mathrm{lt} / \mathrm{m}=1199 \& \mathrm{~s}=68112$.

Vasinauskaitè, Rasa. "Realaus meno bendrija. Oskaro Koršunovo teatro pradžia." Menotyra 14: 4 (2007): 28-46.

White, Gareth. "On Immersive Theatre." Theatre Research International 37: 3 (2012): 221-235.

\section{Notes}

Steve Nelson, "Redecorating the Fourth Wall: Environmental Theatre Today," TDR 33: 3 (1989): 72.

2 Allan Kaprow wrote extensively on Happenings in Excerpts from "Assemblages, environments and happenings" (1995), Happenings in the New York Scene (1961), Essays on the Blurring of Art and Life (1993), and in the audio lecture How to Make a Happening (1966).

3 Michael Kirby, "On acting and non-acting" in Performance, Critical Concepts in Literary and Cultural Studies Volume I, ed. Philip Auslander (London and New York: Routlede, 2003), 318.

4 Richard Schechner, „Six Axioms" in Environmental Theatre (New York: Applause, 1994), xix-li.

5 Erika Fischer-Lichte, Performatyvumo estetika (Vilnius: Menų spaustuvè, 2013), 62.

6 Ibid., 64.

7 Ibid.

8 Ibid., 62-65.

9 Ronald J. Pelias and James Van Oosting, "A paradigm for performance studies" in Performance, Critical Concepts in Literary and Cultural Studies Volume I, ed. Philip Auslander (London and New York: Routledge, 2003), 220.

10 Gay McAuley, Space in Peformance (Chicago: University of Michigan Press, 1999).

11 Jacques Rancière, The Emancipated Spectator (London, New York: Verso, 2009), 3.

12 Ibid., 4.

13 Ibid., 5.

14 Ramunè Marcinkevičiūtè, "Netradicinèse erdvèse. Šiuolaikinio teatro nerimas ir naujų vietų trauka," Darbai ir dienos 39 (2004): 7

15 Ramunè Balevičiūtè, "Epinio, postdraminio ir žaidybinio teatro sankirtos Rimo Tumino režisūroje," Menotyra 19: 2 (2012): 117.

16 For the performance video, see: https://www.lrt.lt/ mediateka/irasas/13020/v-kukulas-r-tuminas-cia-nebusmirties (accessed July 6, 2019).

17 Rasa Vasinauskaite, "Realaus meno bendrija. Oskaro Koršunovo teatro pradžia," Menotyra 14: 4 (2007): 30.

18 Jurgita Staniškyte, "Daugybingumo formos šiuolaikiniame Lietuvos teatre: postmoderni reprezentacija ar modernios tradicijos tęsinys?" Menotyra 18: 2 (2011): 122.

19 Vaidas Jauniškis, "Naujosios teatro realybès. Keletas pastabų dèl terminijos," Menotyra 23: 2 (2016): 123.

20 Ibid., 125.

21 Marcinkevičiūtè, 11.

22 Rūta Mažeikiené, "Postdraminio teatro vaidybos principai ir jų sklaida šiuolaikiniame Lietuvos teatre," Teatrologiniai eskizai 2 (2002): 161.

23 Ibid.

24 Vaidas Jauniškis, "Naujos strategijos jaunųjų scenoje," Menotyra 24: 2 (2017): 135.

25 “'Teatrono' premjera: didele tragedija mažame bute," Menu faktūra, March 6, 2018, http://www.menufaktura. $\mathrm{lt} / \mathrm{m}=1199 \& \mathrm{~s}=68112$.

26 Jurgita Staniškyte, "Spectatorship, Politics and the Rules of Participation: Re-discovering the Audience in Contemporary Lithuanian Theatre," Nordic Theatre Studies 30: 2 (2018): 107.

27 Ibid., 108. 
- 28 Kristina Steiblyte, "Pragmatiškas infantilumas," Menu faktūra, October 1, 2016, http://www.menufaktura. $\mathrm{lt} / \mathrm{?} \mathrm{m}=1025 \& \mathrm{~s}=61226$.

29 Rūta Mažeikienè, "Kolektyviniai naratyvai: bendruomenę įtraukiančio teatro kūrybinès praktikos," Meno istorija ir kritika 11 (2015): 35.

30 Fischer-Lichte, 103-104.

31 Staniškyte, "Spectatorship, Politics and the Rules of Participation," 111.

32 Marcinkevičiūtè, 11

33 Ibid.

34 Staniškytè, "Spectatorship, Politics and the Rules of Participation," 110.

35 Pelias and Van Oosting, 224.

36 Maaike Bleeker, "Corporeal Literacy: New Modes of Embodied Interaction in Digital Culture" in Mapping Intermediality in Performance, ed. Sarah Bay-Cheng et al (Amsterdam: Amsterdam University Press, 2010), 46.

37 Lina Michelkevičè, "Dalyvavimo konfliktai: Dariaus Mikšio projektas 'Už baltos užuolaidos"' Acta Academiae Artium Vilnensis 74 (2014): 145

38 Ibid., 147.

39 Johan Huizinga, "Nature and Significance of Play as a Cultural Phenomenon" in Performance, Critical Concepts in Literary and Cultural Studies Volume I, ed. Philip Auslander (London and New York: Routledge, 2003), 45.

40 Mažeikienè, "Postdraminio teatro vaidybos principai," $157-158$.

41 Pierre Bourdieu, "The forms of capital" in Handbook of Theory and Research for the Sociology of Education, ed. John G. Richardson (New York: Greenwood, 1986), 241-258.

42 Michel Foucault, The Foucault Effect. Studies in Govermentality (Chicago: The University of Chicago Press, 1991), 194

43 Staniškyte, "Spectatorship, Politics and the Rules of Participation," 109.

44 Ibid., 110.

45 Ibid., 101.

46 These political engagements are best explained in Erika Fischer-Lichte's Performatyvumo estetika (2013), where she explains that performance destroys the alleged dichotomies of aesthetic-political relations and highlights specific aesthetic and political links irrespectively of whether the actors and the spectators are established or open up opportunities to manipulate each other. From this point of view, the aesthetic aspect of changing places (the swap) is always political, so it is impossible to separate these two areas. The swap is perceived as political because it involves assigning control features to oneself and others.

47 Nelson, 72

48 Gareth White, "On Immersive Theatre," Theatre Research International 37: 3 (2012): 222.

49 Jurgita Staniškytė, "Komunikacija kaip auditorijų plètros priemonè: Lietuvos teatru praktikos" in Komunikuoti kultūrą: institucijos, strategijos, auditorijos (Kaunas: VDU, 2015), 171.

50 Ramunè Balevičiūtè, "Apie nenugalimą žaidimo trauką ir potyrių spektaklius," Kultūros barai 5 (2017): 55.

\section{Justinas KALINAUSKAS}

Vytauto Didžiojo universitetas, Kaunas, Lietuva

\section{AUDITORIJOS DALYVAVIMAS ŠIUOLAIKINIAME LIETUVOS TEATRE: PRIEŠTARINGA VAKARỤ TRADICIJOS ADAPTACIJA}

\section{Santrauka}

Šiame straipsnyje nagrinejjama, kaip per pastaruosius tris dešimtmečius - nuo 10-ojo dešimtmečio pradžios iki 2-ojo dešimtmečio pabaigos - i Lietuvos teatro lauką buvo ịtrauktas auditorijos dalyvavimo reiškinys ir kaip šiuolaikiniuose Lietuvos teatro projektuose atskleidžiami 7-ojo dešimtmečio Vakarų teatro auditorijos ịtraukimo metodai. Pagrindinis šio straipsnio tikslas - išnagrinèti auditorijos dalyvavimo ir kolektyvinio teatro tradicijos raidą Lietuvos teatre, išanalizuoti dalyvavimo šalies teatro lauke prielaidas, apibrežti dalyvavimo apimtis bei pasireiškiančius prieštaravimus naujausiuose Lietuvos šiuolaikinio teatro pavyzdžiuose. Šie prieštaravimai pastebimi ne tik Lietuvos, bet ir šiandienèse performatyviose Vakarų teatro praktikose, kurios yra nutolusios nuo 7-ojo ir 8-ojo dešimtmečių kolektyvinio teatro praktikų, bet išlaiko ir selektyviai panaudoja tam tikrus aplinkos teatro dalyvavimo aspektus, kurie gali būti pritaikomi naujuose pramoginiuose teatruose. Panaši ribota dalyvaujamojo teatro sklaida Lietuvoje gali būti grindžiama priešinga prielaida - žiūrovų ịpročių pokyčiai nespẻja pasivyti naujai taikomų teatro praktikų, todèl Lietuvos kūrèjai vis dar stengiasi atsargiai sinchronizuoti tradicines stebejimo taktikas su interaktyviomis, taip užkirsdami kelią ir principiniams pokyčiams, susijusiems su pastatymo ir stebejjimo strategijomis. 
Straipsnyje remiamasi Lietuvos teatrologų akademiniais tekstais: Ramunès Balevičiūtès, Rasos Vasinauskaitès, Rūtos Mažeikienès, Jurgitos Staniškytės, Vaido Jauniškio, Linos Michelkevičès ir kitų, siekiant iliustruoti auditorijos dalyvavimo analitinį diskursą ir pristatyti skirtingus dalyvavimo tradicijos etapus Lietuvos teatro istoriografijoje. ApŽvelgiant tarptautinị kontekstą, auditorijos dalyvavimo mechaniką ir istoriją, remtasi Erikos Fischer-Lichte, Michael Kirby, Richardo Schechnerio, Gareth White, Gay McAuley, Johano Huizingos ir kitų autorių tekstais.

Reikšminiai žodžiai: menas, teatras, Lietuvos teatras, auditorijos dalyvavimas, kolektyvinis teatras.

PhD candidate at the Department of Theatre Studies, Faculty of Arts,

Vytautas Magnus University, Kaunas, Lithuania.

E-mail: justinas.kalinauskas@vdu.lt 